\title{
HARTA BERSAMA DALAM PERKAWINAN DI INDONESIA (Menurut Perspektif Hukum Islam)
}

\author{
Amelia Rahmaniah \\ Fakultas Syariah dan Ekonomi Islam IAIN Antasari, Jl. Jenderal Ahmad Yani Km 4,5 Banjarmasin \\ e-mail: amelia.rahmaniah@yahoo.com
}

\begin{abstract}
Joint property in marriage law in Indonesia comes from Indonesian tradition law which is then used as the written law namely Undang-Undang No. 1 Tahun 1974 About Marriage and Compilation of Islamic Law with the aim to provide balanced position between husband and wife. The objective is in line with maqashid al shari'ah. But, the joint property that occur automatically in the written law needs to be reconstructed based on the ownership of Islamic law that the existence of joint property is in line with Islamic law.
\end{abstract}

\begin{abstract}
Abstrak : Harta bersama dalam hukum perkawinan di Indonesia berasal dari hukum adat Indonesia yang kemudian dijadikan hukum tertulis yaitu Undang-Undang No. 1 Tahun 1974 Tentang Perkawinan dan Kompilasi Hukum Islam dengan tujuan untuk memberikan kedudukan yang seimbang antara suami dan isteri. Tujuan tersebut sejalan dengan maqashid al syari'ah. Hanya saja terjadinya harta bersama secara otomatis dalam hukum tertulis tersebut perlu direkonstruksi berdasarkan hukum kepemilikan Islam agar keberadaan harta bersama tersebut selaras dengan hukum Islam.
\end{abstract}

Kata kunci : Harta bersama, maqashid al syari'ah, bukum kepemilikan Islam.

\section{Pendahuluan}

Hukum perkawinan merupakan salah satu bidang perdata di Indonesia yang sudah ada unifikasinya, yaitu yang diatur dalam Undangundang Republik Indonesia Nomor 1 Tahun 1974 Tentang Perkawinan yang memberikan prinsipprinsip dan landasan hukum yang menjadi pegangan bagi bangsa Indonesia. Undang-undang Republik Indonesia Nomor 1 Tahun 1974 Tentang Perkawinan ini merupakan suatu unifikasi yang unik dengan menghormati secara penuh adanya keragaman berdasarkan agama dan kepercayaan yang berketuhanan yang maha esa. Karena itu perkawinan baru sah apabila dilakukan menurut agama dan kepercayaan yang dianut.

Di antara yang diatur dalam Undang-undang Republik Indonesia Nomor 1 Tahun 1974 Tentang Perkawinan adalah mengenai harta benda dalam perkawinan. Pengaturan harta benda dalam perkawinan ini terdapat dalam Pasal 35, 36, 37, dan 65 ayat (1) huruf b dan c.

Dalam Undang-undang Republik Indonesia Nomor 1 Tahun 1974 Tentang Perkawinan ini dikenal ada dua macam harta benda dalam perkawinan yaitu : pertama, harta benda yang diperoleh selama perkawinan yang disebut dengan harta bersama. Kedua, harta bawaan dari masingmasing suami dan isteri dan harta benda yang diperoleh masing-masing sebagai hadiah atau warisan.

Soepomo dalam penelitiannya menguraikan bahwa di seluruh wilayah hukum di Indonesia, harta bawaan tidak termasuk milik bersama. Harta bawaan suami atau isteri masing-masing dalam perkawinan di Banten disebut barang sulur, di daerah hukum Jakarta barang usaha (dari orang tua) dan di daerah lain di Jawa Barat, barang benda, barang asal, barang bawa, barang sasaka dipandang semata-mata milik suami atau isteri yang telah membawanya. ${ }^{1}$

Ketentuan tentang harta bersama menurut Ismuha juga berasal dari hukum adat Indonesia yang diangkat menjadi hukum tertulis. ${ }^{2}$ Undangundang Republik Indonesia Nomor 1 Tahun 1974

\footnotetext{
1 Soerjono Soekanto, Pokok-pokok Sosiologi Hukum, ctk. Ketujuh, ed. Kesatu, RajaGrafindo Persada, Jakarta, 1994, hlm. 144-145

2 Ismail Muhammad Syah, Pencaharian Bersama Suami Isteri di Aceh Ditinjau dari Sudut Undang-undang Perkawinan Tabun 1974 dan Hukum Islam, Disertasi pada Program Doktor dalam Ilmu Hukum Pada Universitas Sumatera Utara, Medan, 1984, hlm. 111
} 
Tentang Perkawinan tidak mengatur secara rinci tentang harta bersama ini seperti yang disebutkan dalam Pasal 37 bahwa "Bila perkawinan putus karena perceraian, harta bersama diatur menurut hukumnya masing-masing”. Menurut Ismuha, tidak adanya pengaturan secara rinci tersebut mungkin karena pembuat undang-undang berpendapat bahwa pengaturan masalah ini secara pasti masih sulit, karena beraneka ragamnya adat mengenai hal ini diberbagai daerah Indonesia. ${ }^{3}$

Sesuai dengan maksud Pasal 37 tersebut maka bagi umat Islam ketentuan yang rinci tentang harta bersama diatur dalam Kompilasi Hukum Islam yang merupakan pedoman bagi Peradilan Agama dan masyarakat yang memerlukan dalam menyelesaikan masalah-masalah di bidang perkawinan, kewarisan dan perwakafan. Sebagai pedoman Kompilasi Hukum Islam tidak hanya harus diperhatikan, tetapi juga mempunyai kekuatan mengikat bagi para hakim Peradilan Agama di Indonesia sejak tingkat pertama, banding sampai kasasi dan Peninjauan Kembali. Kompilasi Hukum Islam merupakan pula pedoman yang harus diperhatikan oleh masyarakat dan karena itu mengikat masyarakat yang bersangkutan. ${ }^{4}$

Kompilasi Hukum Islam yang merupakan perpanjangan tangan dari Undang-undang Nomor 1 Tahun 1974 Tentang Perkawinan yang khusus mengatur harta bersama bagi umat Islam menyebutkan dalam Pasal 1 huruf f bahwa "Harta kekayaan dalam perkawinan atau syirkah adalah harta yang diperoleh baik sendiri-sendiri atau bersama suami isteri selama dalam ikatan perkawinan berlangsung dan selanjutnya disebut harta bersama, tanpa mempersoalkan terdaftar atas nama siapapun". Karena itulah Kompilasi Hukum Islam mengatur bahwa pembagian harta bersama akan dibagi dua di antara suami isteri tersebut apabila terjadi perceraian sepanjang tidak ditentukan lain dalam perjanjian perkawinan.

Jauh sebelum Kompilasi Hukum Islam, Ismuha juga menggolongkan harta bersama ke dalam syirkah yang menyebutnya sebagai syirkah abdan mufawadlah. Dikatakan syirkah abdan karena

3 Ibid., hlm. 112

4 M. Tahir Azhari, "Kompilasi Hukum Islam sebagai Alternatif : Suatu Analisis Sumber-sumber Hukum Islam" dalam Tim Ditbinbapera, Berbagai Pandangan Terbadap Kompilasi Hukum Islam, ctk. Pertama, Yayasan al Hikmah, Jakarta, 1993, hlm. 135-136 kebanyakan pasangan suami isteri dalam masyarakat Indonesia sama-sama bekerja, walaupun isteri hanya bekerja di rumah saja seperti memasak nasi, mengurus pekerjaan rumah tangga dan lainnya. Dan digolongkan ke dalam syirkah mufawadlah karena perkongsian itu tidak terbatas, sebab meliputi apa saja yang dihasilkan oleh suami isteri selama dalam perkawinan. ${ }^{5}$

Di dalam Al Qur-an maupun hadits tidak dikenal keberadaan harta bersama. Al Qur-an maupun hadits tidak memberi ketentuan yang tegas bahwa harta benda yang diperoleh suami selama perkawinan berlangsung sepenuhnya menjadi hak suami, dan isteri hanya terbatas atas nafkah yang diberikan suami. Al Qur-an dan hadits juga tidak menegaskan bahwa harta benda yang diperoleh suami dalam perkawinan secara langsung isteri juga ikut berhak atasnya. Dengan demikian masalah ini adalah masalah ijtihadiah yang termasuk dalam daerah wewenang manusia untuk menentukannya dengan bersumber kepada jiwa ajaran Islam. ${ }^{6}$

Selama ini keberadaan harta bersama digolongkan ke dalam syirkah (sebagaimana pendapatnya Ismuha dan yang dianut oleh Kompilasi Hukum Islam). Penggolongan harta bersama ke dalam syirkah ini telah menimbulkan permasalahan, bisakah kepemilikan dalam harta bersama didasarkan kepada syirkah karena konsep syirkah sangat berbeda dengan konsep harta bersama. Syirkah adalah perikatan yang lahir dari adanya perjanjian (kesepakatan). Sementara harta bersama terbentuk tanpa adanya kesepakatan antara suami isteri bahkan banyak di antara mereka yang tidak mengetahui bahwa harta bersama akan dibagi dua apabila terjadi perceraian. Banyaknya kasus persengketaan di Pengadilan Agama mengenai harta bersama menunjukkan bahwa tidak adanya kesepakatan di antara suami isteri tersebut mengenai pembagian harta bersama.

Karena itulah penelitian ini menjadi sangat penting karena menelaah kembali konsep harta bersama yang berasal dari hukum adat Indonesia dari sudut pandang kepemilikan dalam hukum Islam dan kesesuaiannya dengan maqashid al syari'ah sehingga ditemukan format hukum harta bersama yang mengakomodir hukum adat dan sesuai dengan prinsip hukum Islam.

Ismail Muhammad Syah, op.cit., hlm. 295-296

Ahmad Azhar Basyir, Hukum Perkawinan Islam, ctk. Kesebelas, UII Press, Yogyakarta, 2007, hlm. 66 


\section{Permasalahan}

Berangkat dari latar belakang di atas, maka adapun permasalahan yang akan digali dalam paper ini adalah terkait magaimana konsep harta bersama dalam hukum adat Indonesia?, dan bagaimana konsep harta dalam perkawinan menurut hukum Islam?, serta bagaimana seharusnya hukum positif Indonesia di masa depan dalam pengaturan harta bersama?

\section{Pembahasan}

\section{Konsep harta bersama dalam hukum adat Indonesia}

Perkawinan pada dasarnya di samping merupakan urusan kerabat atau keluarga, juga merupakan urusan yang bersifat perorangan yang akan menimbulkan keterikatan antara hak dan kewajiban para pribadi (suami isteri). Suami umumnya berkedudukan sebagai kepala rumah tangga dan bertanggung jawab serta berkewajiban untuk menjaga kelangsungan hidup rumah tangganya dengan cara memenuhi keperluan hidup rumah tangga baik materiel maupun non materiel. Sedangkan isteri berkewajiban serta bertanggung jawab terhadap penggunaan fasilitas untuk kelangsungan hidup keluarga itu, ia wajib mengatur dan menata penggunaan harta kekayaan untuk kepentingan kehidupan rumah tangga, ia berkewajiban mengurus suami dan anak-anak (bila ada). Gambaran kewajiban isteri ini menunjukkan kedudukan isteri sebagai ibu rumah tangga, akan tetapi kadang-kadang isteri juga berkewajiban membantu suami untuk mencari nafkah. ${ }^{7}$

Perkawinan di samping menimbulkan hak dan kewajiban di antara suami dan isteri, juga mengakibatkan adanya harta bersama dalam sebagian besar masyarakat Indonesia. Ter Haar menyatakan bahwa tidak adanya harta bersama merupakan suatu pengecualian yang besar; hanya pada masyarakat patrilineal dan matrilineal, maka adanya harta keluarga suami (pada kawin jujur) atau harta isteri (pada kawin semendo) tidak memberikan kemungkinan terbentuknya harta bersama, betapapun kecilnya kemungkinan tersebut. Di samping itu juga peranan pribadi dari salah seorang suami atau isteri lebih kuat, sebagaimana halnya pada perkawinan di kalangan orang Sunda antara seorang wanita kaya dengan

Soerjono Soekanto dan Soleman b. Taneko, Hukum Adat Indonesia, Rajawali, Jakarta, hlm. 268 laki-laki miskin (nyalindung kagelung) atau sebaliknya antara laki-laki kaya dengan wanita miskin (manggih kaya) maka hal tersebut merupakan penghalang terbentuknya harta bersama. ${ }^{8}$ Kedudukan harta perkawinan di dalam hukum adat dipengaruhi oleh beberapa hal, yaitu susunan masyarakat adatnya, bentuk perkawinan yang berlaku, dan jenis hartanya. ${ }^{9}$

\section{Susunan masyarakat adat}

Masyarakat Indonesia adalah masyarakat yang plural yang terdiri dari berbagai Suku, Agama, Ras, dan Antar golongan (SARA) yang kemudian bersatu dalam satu kesatuan Negara Indonesia sejak tanggal 17 Agustus 1945. Sebelum Indonesia merdeka, masyarakat yang tinggal di kepulauan besar dan kecil hidup menurut hukum adatnya masing-masing yang menurut catatan ikhtisar yang disusun oleh Ter Haar di masa Hindia Belanda wilayah Indonesia dibaginya ke dalam 19 lingkungan hukum adat (adatrechtskringen)nya masing-masing, sebagai berikut:

1. Aceh (Aceh Besar, Pantai Barat Aceh, Singkel, Simeulue).

2. Daerah-daerah Gayo, Alas, dan Batak

a. Daerah Gayo (Gayo Lueus)

b. Daerah Alas

c. Daerah-daerah Batak (Tapanuli)

i. Tapanuli Utara

1) Batak Pakpak (Barus)

2) Batak Karo

3) Batak Simelungun

4) Batak Toba (Samosir, Balige, Laguboti, Sumban Julu)

ii.Tapanuli Selatan

1) Padang Lawas (Tano Sepanjang).

2) Angkola.

3) Mandailing (sayurmatinggi).

2 a. Nias (Nias Selatan)

3. Daerah Minangkabau (Padang, Agam, Tanahdatar, Limapuluh koto, wilayah Kampar, Kurinci)

3 a. Mentawai (orang-orang Pagai).

$8 \quad$ Ibid., hlm. 274

9 Hilman Hadikusuma, Pengantar Ilmu Hukum Adat Indonesia, ctk. Kedua, Mandar Maju, Bandung, 2003, hlm. 198 


\section{Sumatera Selatan}

a. Bengkulu (Rejang)

b. Lampung (Abung, Peminggir, Pubian, Rebang, Gedongtataan, Tulangbawang).

c. Palembang (Anak Lakitan, Jelma Daya, Kubu, Pasemah, Semendo).

d. Jambi (penduduk Batin dan penduduk Penghulu)

4 a. Enggano.

5. Daerah Melayu (Lingga-Riauw, Indragiri, Sumatera Timur, orang-orang Banjar)

6. Bangka dan Belitung

7. Kalimantan (Dayak, Kalimantan Barat, Kapuas Hulu, Kalimantan Tenggara, Mahakam Hulu, Pasir (Daya Kenya, Daya Klemanten, Daya Landak dan Daya Tayan, Daya Lawangan, Lepo Alim, Lepo Timei, Long Glatt, Daya Maanyan Siung, Daya Ngaju, Daya Ot Danum, Daya Penyabung Punan).

8. Minahasa (Menado).

9. Gorontalo (Bolaang Mongondouw, Boalemo).

10.Daerah Toraja (Sulawesi Tengah, Toraja, Toraja baree, Toraja Barat, Sigi, Kaili, Tawaili, Toraja Sadan, To Mori, To Lainang, Kepulauan Banggai).

11. Sulawesi Selatan (orang-orang Bugis, Bone, Gowa, Laikang, Poure, Mandar, Makasar, selaiar, Muna)

12. Kepulauan Ternate Ternate, Tidore, Halmahera, Tobelo, pulau-pulau Sula).

13. Maluku Ambon (Ambon, Hitu, Banda, pulaupulau Uliaser, Saparua, Buru, Seram, pulaupulau Kei, pulau-pulau Aru, Kaisar).

14.Irian Barat.

15.Kepulauan Timor (kepulauan Timor, Timor, Timor Tengah, Mollo, Sumba, Sumba Tengah, Sumba Timur, Kodi, Flores, Ngada, Rote, Savu, Bima).

16. Bali dan Lombok (Bali, Tenganan Pagringsingan, Kastala, Karang Asem, Buleleng, Jembrana, Lombok, Sumbawa).

17.Jawa Tengah dan Jawa Timur serta Madura (Jawa Tengah, Kedu, Purworejo, Tulungagung, Jawa Timur, Surabaya, Madura).

18.Daerah-daerah Swapraja di Jawa (Solo, Yogyakarta).
19.Jawa Barat (Priangan, Daerah-daerah Sunda, Jakarta, Banten). ${ }^{10}$

Lingkungan hukum adat tersebut adalah berdasarkan kenyataan-kenyataan yang ditemukan sebelum kemerdekaan. Untuk masa sekarang pembagian ini sudah tidak sesuai lagi, dikarenakan terjadinya perubahan dan perkembangan masyarakat. Namun mengenai masyarakat hukum atau persekutuan hukum adat sebagian besar masih tetap hidup dengan hukum adatnya masing-masing berdasarkan ikatan territorial atau berdasarkan ikatan genealogis, dan atau campuran antara keduanya yaitu yang bersifat genealogis-territorial. ${ }^{11}$ Ter Haar merumuskan masyarakat hukum adat, sebagai “... kelompok-kelompok teratur yang sifatnya ajeg dengan pemerintahan sendiri yang memiliki benda-benda materil maupun immateril". ${ }^{12}$

Beberapa macam masyarakat hukum yang dimaksud adalah: pertama, masyarakat hukum territorial adalah masyarakat yang tetap dan teratur, yang anggota-anggota masyarakatnya terikat pada suatu daerah kediaman tertentu, baik dalam kaitan duniawi sebagai tempat kehidupan maupun dalam kaitan rohani sebagai tempat pemujaan terhadap roh-roh leluhur. Menurut Van Dijk, persekutuan hukum territorial itu dapat dibedakan menjadi tiga macam, yaitu persekutuan desa, persekutuan daerah, atau perserikatan desa. Setelah berlakuknya Undang-undang Pemerintahan Desa No. 5 Tahun 1979 (LN 1975-56) maka ketiga bentuk desa tersebut tidak lagi bersifat formal, akan tetapi berubah menjadi desa-desa adat yang informal. ${ }^{13}$

Kedua, masyarakat hukum genealogis, yaitu suatu kesatuan masyarakat yang teratur, di mana para anggotanya terikat pada suatu garis keturunan yang sama dari satu leluhur yang sama baik secara langsung karena hubungan darah (keturunan) atau secara tidak langsung karena pertalian perkawinan atau pertalian adat. Masyarakat genealogis ini dapat dibedakan menjadi tiga macam, yaitu yang bersifat patrilinial, matrilinial, dan bilateral atau parental. ${ }^{14}$

Masyarakat yang patrilinial adalah yang susunan masyarakatnya ditarik menurut garis

\footnotetext{
${ }^{10}$ Ibid., hlm. 5-7

11 Ibid., hlm. 106

${ }^{12}$ Soerjono Soekanto dan Soleman b. Taneko, op.cit., hlm. 108

${ }^{13}$ Hilman Hadikusuma, op.cit., hlm. 106-107

${ }^{14}$ Ibid., hlm. 108
} 
keturunan bapak (garis lelaki), sedangkan garis keturunan ibu disingkirkan. Masyarakat patrilinial misalnya di Batak dengan nama marga Situmorang, Sinaga, Pandiangan, Nainggolan, Simatupang, Aritonang, Siregar, dan sebagainya. Di Lampung dengan nama marga Buwai Nunyai, Buwai Unyi, Buwai Nuban, Buwai Subing, Buwai Bolan, dan sebagainya. Masyarakat patrilinial juga terdapat di Bali, Nusatenggara (Timor), Maluku, dan Irian. ${ }^{15}$

Masyarakat yang matrilinial adalah yang susunan masyarakatnya ditarik menurut garis keturunan ibu (garis perempuan), sedangkan garis keturunan bapak disingkirkan, misalnya kekerabatan di Minangkabau, Kerinci, Semendo di Sumatera Selatan dan beberapa suku kecil di Timor. Masyarakat ini tidak mudah dikenal karena walaupun ada nama-nama keturunan sukunya, tetapi jarang digunakan secara umum. ${ }^{16}$

Masyarakat yang bilateral atau parental adalah yang susunan masyarakatnya ditarik menurut garis keturunan orang tua, yaitu bapak dan ibu bersamasama, seperti terdapat di Mollo (Timor) dan banyak di Melanesia. Tetapi kebanyakan sifatnya terbatas dalam beberapa generasi saja seperti di kalangan masyarakat Aceh, Melayu, Jawa, Kalimantan dan Sulawesi. ${ }^{17}$

Ketiga, masyarakat territorial-genealogis adalah kesatuan masyarakat yang tetap dan teratur di mana para anggotanya bukan saja terikat pada tempat kediaman pada suatu daerah tertentu tetapi juga terikat pada hubungan keturunan dalam ikatan pertalian darah dan atau kekerabatan. ${ }^{18}$

Keempat, masyarakat adat-keagamaan, yaitu kesatuan masyarakat adat yang khusus bersifat keagamaan. Ada kesatuan masyarakat yang khusus beragama Hindu, Islam, Kristen/Katolik, dan ada yang bersifat campuran. ${ }^{19}$ Kelima, masyarakat adat di perantauan, misalnya seperti orang Aceh, Batak, Minangkabau, dan lain-lain yang berada di perantauan cenderung untuk membentuk kelompok-kelompok kumpulan kekeluargaan, seperti rukun kematian, atau bahkan membentuk kesatuan masyarakat adat yang berfungsi sebagai pengganti kerapatan adat di kampung asalnya. ${ }^{20}$ Keenam, masyarakat adat lainnya, yaitu bentuk-

\footnotetext{
${ }^{15}$ Ibid., hlm. 108-109

16 Ibid., hlm. 109

${ }^{17}$ Ibid.

${ }^{18}$ Ibid., hlm. 110

${ }^{19}$ Ibid., hlm. 111
}

bentuk kumpulan organisasi yang ikatan anggotaanggotanya didasarkan pada ikatan kekaryaan sejenis yang tidak berdasarkan pada hukum adat yang sama atau daerah asal yang sama, melainkan pada rasa kekeluargaan yang sama dan terdiri dari berbagai suku bangsa dan berbeda agama. ${ }^{21}$

\section{Bentuk perkawinan yang berlaku}

Perkawinan menurut hukum adat merupakan urusan keluarga, urusan persekutuan, urusan status dan pribadi, yang satu dengan yang lain sangat tidak seimbang. ${ }^{22}$ Bentuk perkawinan yang berlaku di Indonesia berbeda antara susunan masyarakat yang bersifat patrilinial, matrilinial, parental dan campuran. Adapun bentuk-bentuk perkawinan yang berlaku adalah pertama, perkawinan jujur adalah perkawinan dengan pemberian (pembayaran) uang (barang) jujur. Pada umumnya ini berlaku di lingkungan masyarakat hukum adat yang mempertahankan garis keturunan bapak (lelaki), misalnya di Gayo, Batak, Nias, Lampung, Bali, Timor, Maluku. Pemberian uang/barang jujur dilakukan oleh pihak kerabat calon suami kepada pihak kerabat calon isteri, sebagai tanda pengganti pelepasan mempelai wanita keluar dari kewargaan adat persekutuan hukum bapaknya, pindah dan masuk ke dalam persekutuan hukum suaminya. ${ }^{23}$

Kedua, perkawinan semenda, yang pada umumnya berlaku di lingkungan masyarakat adat matrilinial. Dalam perkawinan semanda, calon mempelai pria dan kerabatnya tidak melakukan pemberian uang jujur kepada pihak wanita, malahan sebagaimana berlaku di Minangkabau berlaku adat pelamaran dari pihak wanita kepada pihak pria. Setelah perkawinan terjadi maka suami berada di bawah kekuasaan kerabat isteri dan kedudukan hukumnya bergantung pada bentuk perkawinan semenda yang berlaku. ${ }^{24}$ Pada umumnya dalam

\footnotetext{
${ }^{20}$ Ibid., hlm. 113

${ }^{21}$ Ibid., hlm. 114-115

22 B. Ter Haar Bzn, Asas-asas dan Tatanan Hukum Adat, disadur oleh Freddy Tengker, ctk. Pertama, Mandar Maju, Bandung, 2011, hlm. 137

${ }^{23}$ Hilman Hadikusuma, op.cit., hlm. 183-184

${ }^{24}$ Jika bentuk perkawinannya "semenda raja-raja" berarti suami isteri berkedudukan sama (seimbang) baik di pihak isteri maupun di pihak suami, jika "semenda lepas" berarti suami mengikuti tempat kediaman isteri, jika "semenda bebas" berarti suami tetap pada kerabat orang tuanya sebagai di Minangkabau ia hanya "urang sumando", jika "semanda nunggu" maka suami isteri berkediaman di
} 
perkawinan semenda kekuasaan pihak isteri yang sangat berperan, sedangkan suami tidak ubahnya sebagai istilah "nginjam jago" sebagai pemberi bibit saja dan kurang bertanggung jawab dalam rumah tangga. ${ }^{25}$

Ketiga, perkawinan bebas (mandiri), ini biasanya berlaku di lingkungan adat yang bersifat parental (keorang-tuaan), seperti berlaku di kalangan masyarakat Jawa, Sunda, Aceh, Melayu, Kalimantan, Sulawesi, dan di kalangan masyarakat Indonesia yang modern, di mana keluarga atau kerabat tidak banyak lagi campurtangan dalam rumah tangga. ${ }^{26}$

Keempat, perkawinan campuran, adalah perkawinan yang terjadi di antara suami dan isteri yang berbeda suku bangsa, adat budaya, dan atau berbeda agama yang dianut. ${ }^{27}$

Kelima, perkawinan lari, perkawinan ini banyak terjadi di kalangan masyarakat Batak, Lampung, Bali, Bugis/Makasar, Maluku. Perkawinan ini dapat dibedakan menjadi perkawinan lari bersama dan perkawinan lari paksaan. ${ }^{28}$

\section{Harta kekayaan dalam perkawinan}

Harta kekayaan dari suami isteri dalam sebuah keluarga dapat dibedakan menjadi empat jenis, yaitu pertama harta kekayaan suami atau isteri yang merupakan warisan atau hibah dari para kerabat. Kedua, harta kekayaan yang berasal dari usaha suami ataupun isteri yang diperoleh sebelum atau selama perkawinan berlangsung. Ketiga, harta kekayaan yang berasal dari hadiah pada waktu perkawinan. Keempat,

pihak kerabat isteri selama menunggu adik isteri (ipar) sampai dapat mandiri, jika "semenda ngangkit" maka suami mengambil isteri untuk dijadikan penerus keturunan pihak ibu suami dikarenakan ibu tidak mempunyai keturunan anak wanita, jika "semenda anak dagang" maka suami tidak menetap di tempat isteri melainkan datang sewaktu-waktu, kemudian pergi lagi seperti burung yang hinggap sementara, maka disebut juga "semanda burung". Lihat ibid., hlm. 185

25 Ibid., hlm. 186

${ }^{26}$ Ibid.

27 Ibid., hlm. 188

${ }^{28}$ Perkawinan lari bersama biasanya dilakukan dengan mengikuti tata-tertib adat setempat, sedangkan perkawinan lari paksaan adalah perbuatan melarikan gadis dengan akal tipu, atau dengan paksaan atau kekerasan, tidak atas persetujuan si gadis dan tidak menurut tata tertib adat. Lihat Ibid., hlm. 189-190 harta kekayaan sebagai usaha bersama antara suami isteri. ${ }^{29}$

Mengenai harta kekayaan dalam perkawinan ini, Ter Haar menyatakan bahwa pada umumnya pengaturan tentang barang asal tetap terikat pada keluarga asal, sedangkan tentang harta kekayaan sebagai usaha bersama antara suami isteri adalah merupakan harta bersama yang pada waktu terjadi perceraian akan menimbulkan hak dari suami dan isteri atas harta tersebut (masing-masing sebagian). ${ }^{30}$

Tidak adanya harta bersama merupakan suatu pengecualian, misalnya pada masyarakat adat patrilinial dengan bentuk perkawinan jujur, di mana isteri kedudukannya tunduk kepada hukum kekerabatan suami maka pada umumnya semua harta perkawinan dikuasai oleh suami sebagai kepala keluarga/rumah tangga dan dibantu oleh isteri sebagai ibu keluarga/rumah tangga. Jadi semua harta seperti harta pencarian (harta bersama), harta bawaan (hadiah dan warisan) dan harta pusaka (harta peninggalan), penguasaannya (hak pengaturannya) untuk kehidupan keluarga/ rumah tangga dipegang oleh suami yang dibantu oleh isteri sebagai pendampingnya. Setelah perkawinan, isteri mengikuti tempat kediaman suami dan tidak akan kembali lagi kepada orang tua atau kerabatnya (karena perceraian), ia akan hidup selamanya di tempat kedudukan suaminya sampai akhir hayatnya. Jika terjadi perceraian dan isteri meninggalkan tempat kedudukan suaminya berarti isteri melanggar adat, dan dia tidak berhak menuntut bagian dari harta bersama, ataupun terhadap harta bawaannya, ataupun membawa anaknya pergi dari tempat kediaman suaminya. ${ }^{31}$ Akan tetapi pada masyarakat patrilinial di Bali, dikenal adanya harta bersama (gunakaya). ${ }^{32}$

Sedangkan pada masyarakat adat yang susunannya matrilinial dan bentuk perkawinannya adalah semanda (tanpa membayar jujur) maka terdapat pemisahan kekuasaan terhadap harta perkawinan. Kekuasaan terhadap harta pusaka milik bersama kerabat dipegang oleh mamak kepala waris sedangkan isteri dan suami dalam hal ini hanya mempunyai hak "ganggam bauntuik" (hak mengusahakan dan menikmati hasil panen terhadap

\footnotetext{
29 Soerjono Soekanto dan Soleman b. Taneko, op.cit., hlm. 269-273

30 Ibid., hlm. 274

31 Hilman Hadikusuma, op.cit., hlm. 198

32 Soerjono Soekanto dan Soleman b. Taneko, loc.cit.
} 
sebidang tanah; hak mendiami terhadap rumah gadang). Tetapi terhadap harta pencarian (harta suarang), suami isteri secara bersama menguasainya; sedangkan terhadap harta bawaan masing-masing dikuasai oleh masing-masing. ${ }^{33}$

Pada masyarakat adat yang susunannya parental, di mana kedudukan suami isteri sejajar, maka harta bersama (Jawa: gono gini, Sunda: guna kaya, Aceh: areuta sihareukat) dikuasai bersama untuk kepentingan bersama, sedangkan harta bawaan dikuasai oleh masing-masing suami isteri, kecuali dalam hal perkawinan kedudukan suami dan isteri tidak sejajar. Misalnya dalam bentuk perkawinan "manggih kaya" di Jawa di mana suami lebih kaya dan isteri miskin maka harta bersama dikuasai oleh suami sendiri, atau sebaliknya isteri kaya sedang suami miskin misalnya di Pasundan dalam bentuk perkawinan "nyalindung Kagelung" maka harta bersama dikuasai oleh isteri. ${ }^{34}$

Berdasarkan uraian sebelumnya maka pada umumnya harta bersama ada kalau ada kehidupan bersama antara suami isteri, dan keduanya mempunyai kedudukan yang sama dalam masyarakat. Sedangkan prinsip garis keturunan tidak menentukan ada atau tidaknya harta bersama tersebut. ${ }^{35}$

\section{Konsep harta dalam perkawinan menurut hukum Islam}

Perkawinan atau an nikah adalah menghimpun atau mengumpulkan. Ulama Mazhab Syafi'i mendefinisikannya dengan akad yang mengandung kebolehan melakukan hubungan suami isteri dengan lafal nikah/kawin atau yang semakna dengan itu. Sedangkan menurut Ulama Mazhab Hanafi adalah akad yang memfaedahkan halalnya melakukan hubungan suami isteri antara seorang lelaki dengan seorang perempuan selama tidak ada halangan syara'. Abu Zahrah mengkompromikan kedua definisi tersebut, yaitu akad yang menjadikan halalnya hubungan seksual antara seorang laki-laki dan seorang wanita, saling tolong-menolong di antara keduanya serta menimbulkan hak dan kewajiban antara keduanya. Hak dan kewajiban yang dimaksudkan Abu Zahrah adalah hak dan

\footnotetext{
33 Hilman Hadikusuma, op.cit., hlm. 198-199

34 Ibid., hlm. 199

35 Soerjono Soekanto dan Soleman b. Taneko, op.cit., hlm. 275
}

kewajiban yang datangnya dari asy Syari' (Allah SW'T dan Rasul-Nya). ${ }^{36}$

Hak-hak dalam perkawinan dapat dibagi menjadi tiga, yaitu hak bersama, hak isteri yang menjadi kewajiban suami, dan hak suami yang menjadi kewajiban isteri. Diantara hak bersama adalah bergaul dengan baik antara suami isteri, saling mewarisi antara suami isteri. Sedangkan hak isteri yang menjadi kewajiban suami dapat dibagi menjadi dua, yaitu hak kebendaan yang berupa mahar dan nafkah, dan hak bukan kebendaan, misalnya tidak berbuat yang merugikan isteri dan berbuat adil bagi yang poligami. Adapun hak suami yang wajib dipenuhi oleh isteri hanya merupakan hak bukan kebendaan sebab menurut hukum Islam isteri tidak dibebani kewajiban kebendaan yang diperlukan untuk mencukupkan kebutuhan hidup keluarga. Diantara hak suami adalah hak untuk ditaati dan hak memberi pelajaran kepada isteri dengan cara yang baik dan layak dengan kedudukan suami isteri. ${ }^{37}$

Hukum Islam memberi hak kepada masingmasing suami isteri untuk memiliki harta benda secara perorangan, yang tidak dapat diganggu oleh pihak lain. ${ }^{38}$ Persoalannya adalah apakah hukum Islam mentolerir adanya harta bersama dalam perkawinan sebagaimana yang dianut oleh Undangundang No. 1 Tahun 1974 Tentang Perkawinan dan Kompilasi Hukum Islam.

Persoalan harta bersama ini akan dilihat dari perspektif kepemilikan dalam hukum Islam, karena dari sini akan diketahui status kepemilikan harta dalam perkawinan.

Hukum Islam mengakui adanya kepemilikan individu sebagaimana yang disebutkan dalam surah an Nisa ayat 32 yang menyebutkan bahwa bagi lakilaki ada bahagian dari apa yang mereka usahakan, dan bagi para perempuan (pun) ada bahagian dari apa yang mereka usahakan. Abdul Sami' al Mishri mengatakan bahwa sebagai agama yang sesuai dengan fitrah manusia, Islam telah menetapkan adanya kebolehan setiap individu untuk memiliki harta benda secara pribadi. ${ }^{39}$ Kepemilikan

36 Abdul Aziz Dahlan, dkk. (ed.), Ensiklopedi Hukum Islam, ctk. Kelima, Jilid Keempat, Ichtiar Baru van Hoeve, Jakarta, 2001, hlm. 1329

${ }^{37}$ Ahmad Azhar Basyir, op.cit., hlm. 53-61

${ }^{38}$ Ibid., hlm. 65

39 Abdul Sami' al Mishri, Muqawwimat al Iqtishad al Islami, diterjemahkan oleh Dimyauddin Djuwaini, dengan judul 
merupakan izin asy Syari' untuk memanfaatkan zat tertentu, karena itulah kepemilikan tidak akan ditetapkan selain dengan ketetapan dari asy Syari' terhadap zat tersebut, serta sebab-sebab pemilikannya, sehingga melahirkan akibat adanya pemilikan atas zat tersebut sah secara syar'i. ${ }^{40}$

Kepemilikan individu dibagi kepada kepemilikan sempurna (milk al taam) dan kepemilikan tidak sempurna (milk al naqish). Kepemilikan sempurna adalah kepemilikan terhadap fisik benda atau harta dan manfaatnya sekaligus, sedangkan kepemilikan tidak sempurna adalah kepemilikan terhadap fisik benda saja tanpa memiliki manfaatnya atau sebaliknya memiliki manfaat benda tetapi tidak memiliki fisiknya. ${ }^{41}$

Kepemilikan individu yang sempurna dapat diperoleh melalui salah satu dari empat sebab kepemilikan, yaitu :

1. Ihrazul mubabat ialah memiliki benda-benda yang boleh dimiliki. Yang dikatakan mubah itu ialah harta yang tidak masuk ke dalam milik yang dihormati (miliki seseorang yang sah) dan tidak ada pula sesuatu penghalang yang dibenarkan syara' dari memilikinya, seperti air yang tidak dimiliki seseorang, ikanikan di lautan, rumput dan pepohonan di hutan, dan lain-lain. Memiliki benda yang mubah dengan jalan ibraz memerlukan dua syarat yaitu tidak diibrazkan orang lain lebih dahulu dan ada maksud tamalluk.

2. Al uqud ialah perikatan $\ddot{j a b}$ dan kabul secara yang disyariatkan agama nampak bekasannya pada yang diakadkan itu. ${ }^{42}$

3. Khalafiyah ialah bertempatnya seseorang atau sesuatu yang baru di tempat yang lama yang telah hilang, pada berbagai macam rupa hak.

Pilar-pilar Ekonomi Islam, Pustaka Pelajar, Yogyakarta, 2006, hlm. 30

${ }^{40}$ Taqyuddin an Nabhani, An Nidlam al Iqtishadi fil Islam, diterjemahkan oleh Moh. Maghfur Wachid, dengan judul Membangun Sistem Ekonomi Alternatif; Perspektif Islam, ctk. Ketujuh, Risalah Gusti, Surabaya, 2002, hlm. 67

${ }^{41}$ Wahbah al Zuhaili, Al Fiqh al Islami wa Adillatuhu., ctk. Ketiga, Juz IV, Dar al Fikr, Damasqus, 1989, hlm. 58-59

${ }^{42}$ Akad didefinisikan sebagai pertemuan ijab yang dinyatakan oleh salah satu pihak dengan kabul dari pihak lain secara sah menurut syara' yang tampak akibat hukumnya pada obyeknya. Lihat Syamsul Anwar, Hukum Kontrak Syariah, Bahan Kuliah Magister Hukum UII, Yogyakarta, 2007, hlm. 26
Khalafiyah terbagi dua yaitu pewarisan dan kompensasi.

4. Tawallud minal mamluk ialah segala yang terjadi dari benda yang dimiliki, menjadi hak bagi yang memiliki atau dengan kata lain lahir dari milik sendiri, misalnya anak binatang menjadi pemilik binatang. ${ }^{43}$

Dari keempat sebab kepemilikan yang dibenarkan oleh syara' tersebut maka kepemilikan harta dalam perkawinan sebagai harta bersama hanya bisa dibenarkan oleh syara' dengan jalan akad (sebab kepemilikan no. 2).

Terkait dengan masalah akad ini, ada yang berpendapat bahwa dengan adanya akad nikah maka secara otomatis terjadi harta bersama. Akad nikah mengandung persetujuan kongsi dalam membina rumah tangga, dengan demikian seluruh harta yang diperoleh setelah terjadinya akad nikah dianggap harta bersama suami isteri tanpa mempersoalkan jerih payah siapa yang lebih banyak dalam usaha memperoleh harta tersebut. ${ }^{44}$

Penulis tidak sependapat dengan pendapat yang mengatakan bahwa dengan adanya akad nikah maka otomatis akan terjadi harta bersama karena secara normatif dan praktek sepanjang sejarah Islam tidak dikenal adanya harta bersama. Penulis juga berpendapat bahwa akad nikah bukanlah akad perkongsian (Syirkah) dengan berdasarkan kepada kaidah ushul al umuru bimaqashidiha (tiap perkara tergantung pada maksudnya), akad nikah termasuk lafal yang jelas (al lafž ash sharih) karena itulah akad nikah yang diucapkan hanya mengandung maksud akad nikah saja (tanpa mengandung kemungkinan makna yang lain) dengan segala konsekuensi hukumnya, sedangkan perkongsian (syirkab) adalah akad yang tersendiri yang bukan integral dalam akad nikah.

Konsep harta bersama yang terbentuk secara otomatis ini, juga tidak relevan dengan konsep

43 T.M. Hasbi ash Shiddieqy, Pengantar Fikih Mu'amalah, ctk. Pertama, Bulan Bintang, Jakarta, 1974, hlm. 19-23. Lihat juga Wahbah al Zuhaili, op.cit., hlm. 70-77 dan Dimyauddin Djuwaini, Pengantar Fiqh Muamalah, ctk. Pertama, Pustaka Pelajar, Yogyakarta, 2008, hlm. 42

${ }^{44}$ Dedi Susanto, Kupas Tuntas Masalah Harta Gono-Gini, ctk. Pertama, Pustaka Yustisia, Yogyakarta, 2011, hlm. 130. Lihat juga Departemen Agama RI, Tinjauan Figh Islam terhadap Putusan Pengadilan Agama dalam Perkara Harta Bersama, Direktorat Pembinaan Peradilan Agama Direktorat Jenderal Bimbingan Masyarakat Islam dan Penyelenggaraan Haji, Jakarta, 2004, hlm. 7-8 
nafkah dan mut'ah dalam Islam. Konsep nafkah dalam Islam jelas merujuk kepada adanya perbedaan antara harta suami dan harta isteri, suami sebagai pemberi nafkah dan isteri sebagai penerima nafkah. Sedangkan dalam konsep harta bersama semua harta menjadi harta bersama yang dikuasai secara bersama-sama sehingga tidak relevan dengan konsep nafkah. Demikian juga dengan konsep mut'ah yang juga tidak relevan dengan konsep harta bersama karena adanya mut'ah sebagai pemberian suami kepada isteri yang dicerai tidak diperlukan lagi karena isteri sudah mendapat bagian dari harta bersama.

Terkait dengan harta bersama ini maka diperlukan berbagai macam pendekatan, seperti pendapat Muslich bahwa untuk dapat memahami substansi agama maka umat Islam harus menggunakan berbagai macam pendekatan (interdisipliner) agar substansi nilai-nilai agama yang terdapat dalam al Qur-an dan hadits dapat ditangkap dan kemudian dipadukan dengan lokalitas kebudayaan. Hal ini bertujuan agar manusia dapat membentuk kebudayaan yang penuh cita rasa dan bersendikan moral. ${ }^{45}$

Upaya yang seperti ini dilakukan oleh Louay Safi melalui pendekatan terpadu hukum Islam dan sosial (a unified approach to shari' ah and sosial inference). Ilmu sosial yang dimaksud oleh Safi adalah ilmu sosial kemanusiaan (humaniora) secara umum, yang memiliki karakter historis dan empiris. ${ }^{46}$ Menurut Safi, kasus hukum baru yang belum ada ketentuan hukumnya di dalam teks maka analisis empiris bertujuan untuk membangun fondasi hukum bagi kasus tersebut. Menurut Safi realitas empiris (misalnya adat) harus direkonstruksi- sistem aturan dan tujuannya- hal ini didasarkan pada kesimpulan inferensi terpadu Safi bahwa suatu aksi kolektif (fenomena sosial empiris) maupun wacana (wahyu) memiliki sistem aturan dan tujuan sehingga memungkinkan dilakukannya upaya mempersatukan, memperbandingkan, atau mempertentangkannya. ${ }^{47}$

\footnotetext{
${ }^{45}$ Slamet Abdullah dan M. Muslich KS., Seabad Mubammadiyah dalam Pergumulan Budaya Nusantara, Edisi Pertama, ctk. Pertama, Global Pustaka Utama, Yogyakarta, 2010, hlm. 216-217

${ }^{46}$ Mahsun Fuad, Hukum Islam Indonesia; dari Nalar Partisipatoris hingga Emansipatoris, ctk. Pertama, LKiS, Yogyakarta, 2005, hlm. 262

${ }^{47}$ Ibid., hlm. 270
}

Terkait dengan harta bersama maka berdasarkan pendapat Safi yang menggunakan analisis empiris maka perlu diungkap motif dan tujuan dari adanya harta bersama dalam sebagian masyarakat Indonesia yang kemudian dijadikan hukum positif. Berdasarkan uraian sebelumnya maka pada umumnya harta bersama dalam masyarakat Indonesia ada kalau ada kehidupan bersama antara suami isteri, dan keduanya mempunyai kedudukan yang sama dalam masyarakat, kedudukan yang seimbang ini pula yang menjadi asas dari Undang-undang No. 1 Tahun 1974 Tentang Perkawinan. ${ }^{48}$

Motif dari adanya harta bersama dalam masyarakat Indonesia untuk memberikan kedudukan yang seimbang antara suami dan isteri ini adalah sejalan dengan maqashid al syari'ab yang menurut Shatibi bahwa tujuan utama dari syari'ah adalah maslahah manusia. ${ }^{49} \mathrm{Al}$ Gazzali berpendapat bahwa maslahah yang sah secara syar'i adalah maslahah yang didukung oleh nass atau maslahah yang selaras dengan genus tindakan syara', artinya selaras dengan semangat syara' secara umum. Maslahah yang bertentangan dengan nass-nass syari'ah tidak dapat menjadi dasar penemuan hukum syar'i. ${ }^{50}$

Masalah harta bersama ini kalau dilihat dari teori maqashid al syari'ah maka akan berada pada skala dharuriyyat ${ }^{51}$ yaitu untuk menyelamatkan harta.

48 Salah satu asas atau prinsip dari Undang-undang No. 1 Tahun 1974 Tentang Perkawinan adalah hak dan kedudukan isteri adalah seimbang dengan hak dan kedudukan suami baik dalam kehidupan rumah tangga maupun dalam pergaulan masyarakat, sehingga dengan demikian segala sesuatu dalam keluarga dapat dirundingkan dan diputuskan bersama oleh suami isteri. Lihat Sudarsono, Hukum Perkaminan Nasional, ctk. Kedua, Rineka Cipta, Jakarta, 1994, hlm. 9

49 Muhammad Khalid Mas'ud, Islamic Legal Philosofy: A Study of Abu Ishaq al Shatibi's Life and Thought, diterjemahkan oleh Yudian W. Asmin, dengan judul Filsafat Hukum Islam dan Perubahan Sosial, ctk. Pertama, Al Ikhlas, Surabaya, 1995, hlm.229

${ }^{50}$ Moh. Mukri, Paradigma Maslahah dalam Pemikiran al Gazzali; Sebuah studi Aplikasi dan Implikasi terhadap Hukum Islam Kontemporer, ctk. Pertama, Pesantren Nawesea Press, Yogyakarta, 2011, hlm. 118

${ }^{51}$ Dharuriyyat (keharusan-keharusan atau keniscayaankeniscayaan) yaitu sesuatu yang harus ada demi kelangsungan kehidupan manusia. Jika sesuatu itu tidak ada maka kehidupan manusia pasti akan hancur. Adapun kepentingan-kepentingan yang dilindungi adalah agama, jiwa, akal, harta, keturunan, dan harga diri (kehormatan). 
Untuk menyelamatkan harta ini maka Islam mensyari'atkan diantaranya hukum-hukum muamalat sekaligus melarang langkah-langkah yang akan merusaknya. ${ }^{52}$ Karena itulah maka kepemilikan dalam harta bersama haruslah sesuai dengan ketentuan kepemilikan dalam hukum Islam dalam rangka untuk melindungi atau menyelamatkan harta.

Dilihat dari segi ketentuan harta bersama yang ada di dalam masyarakat Indonesia yang terjadi secara otomatis maka menurut Penulis hal ini tidak sesuai dengan ketentuan kepemilikan yang dibenarkan dalam Islam. Hal yang memungkinkan harta bersama dimiliki secara bersama-sama (bagi yang bekerja menghasilkan uang dan yang tidak menghasilkan uang) adalah dengan akad (kesepakatan), tanpa akad maka hal itu tidak akan terjadi. Taqyuddin an Nabhani berpendapat bahwa harta yang halal adalah harta yang diperoleh sesuai dengan makna kepemilikan yaitu sesuai dengan mekanisme tertentu (sesuai dengan sebab-sebab kepemilikan yang telah disyari'atkan dan adanya batasan-batasan tertentu). Sedangkan harta yang haram adalah harta yang tidak diperoleh sesuai dengan makna kepemilikan tersebut. ${ }^{53}$ Karena itulah menurut Penulis, akad menduduki tempat yang sangat penting bagi terbentuknya harta bersama.

\section{Hukum positif Indonesia di masa depan dalam pengaturan harta bersama}

Berdasarkan penjelasan sebelumnya maka konsep harta bersama di Indonesia berasal dari hukum adat yang kemudian ditingkatkan menjadi hukum positif yaitu diatur dalam Undang-undang No. 1 Tahun 1974 Tentang Perkawinan dan

Lihat, Yudian Wahyudi, Maqashid Syari'ah dalam Pergumulan Politik; Berfilsafat Hukum Islam dari Harvard ke Sunan Kalijaga, ctk. Ketiga, Pesantren Nawesea Press, Yogyakarta, 2007, hlm. 29-30. Lihat juga, Yudian Wahyudi, Ushul Fikih Versus Hermeneutika; Membaca Islam dari Kanada dan Amerika, ctk. Ketujuh, Pesantren Nawesea Press, Yogyakarta, 2011, hlm. 45. Dharuriyyat menurut al Gazzali adalah kepentingan yang harus ada untuk terwujudnya kemaslahatan dunia dan akhirat di mana apabila kepentingan itu tidak ada maka kelangsungan hidup di dunia tidak dapat dipertahankan dan di akhirat akan mengalami kerugian eskatologis. Lihat Moh. Mukri, Ibid.

${ }^{52}$ Yudian Wahyudi, Ushul Fikih Versus Hermeneutika ..., Ibid.

53 Taqyuddin an Nabhani, op.cit., hlm. 70
Kompilasi Hukum Islam (bagi yang beragama Islam).

Harta benda dalam perkawinan diatur dalam Bab VII Pasal 35, 36, dan 37 Undang-undang No. 1 Tahun 1974 Tentang Perkawinan, yaitu:

Pasal 35:

(1) Harta benda yang diperoleh selama perkawinan menjadi harta bersama

(2) Harta bawaan dari masing-masing suami dan isteri dan harta benda yang diperoleh masing-masing sebagai hadiah atau warisan, adalah di bawah penguasaan masing-masing sepanjang para pibake tidak menentukan lain.

Pasal 36

(1) Mengenai harta bersama, suami atau isteri dapat bertindak atas persetujuan kedua belah pibak.

(2) Mengenai harta bawaan masing-masing suami dan isteri mempunyai hak sepenubnya untuk melakukan perbuatan bukum mengenai harta bendanya.

Pasal 37

Bila perkawinan putus karena perceraian, harta bersama diatur menurut hukumnya masing-masing.

Penjelasan atas Undang-undang No. 1 Tahun 1974 Tentang Perkawinan dari pasal-pasal tersebut adalah:

Pasal 35

Apabila perkawinan putus, maka harta bersama tersebut diatur menurut Hukumnya masing-masing.

Pasal 36

Cukup jelas.

Pasal 37

Yang dimaksud dengan "bukumnya" masingmasing ialah bukum agama, bukum adat dan bukum-bukum lainnya.

Sedangkan di dalam Kompilasi Hukum Islam tentang harta kekayaan dalam perkawinan disebutkan dalam Bab I Pasal 1 Huruf f dan Bab XIII Pasal 85 - 97, di antara pasal tersebut adalah:

Pasal 1

f. Harta kekayaan dalam perkawinan atau syirkah adalah harta yang diperoleh baik sendiri-sendiri atau bersama suami isteri selama dalam ikatan 
perkawinan berlangsung dan selanjutnya disebut harta bersama, tanpa mempersoalkan terdaftar atas nama siapapun.

\section{Pasal 85}

Adanya harta bersama dalam perkawinan itu tidak. menutup kemungkinan adanya harta milk masingmasing suami dan isteri.

Pasal 86

(1) Pada dasarnya tidak ada percampuran antara harta suami dan harta isteri karena perkawinan

(2) Harta isteri tetap menjadi hak isteri dan dikuasai penub olehnya, demikian juga harta suami tetap menjadi hak suami dan dikuasai penub olebnya.

Pada prinsipnya Undang-undang No. 1 Tahun 1974 Tentang Perkawinan menganut adanya harta bersama secara otomatis. Akan tetapi dalam Kompilasi Hukum Islam tidak ada pernyataan yang tegas mengenai terbentuknya harta bersama secara otomatis, terutama dalam Pasal 86 ayat (1) "Pada dasarnya tidak ada percampuran antara harta suami dan harta isteri karena perkawinan".

Seperti yang telah disebutkan sebelumnya bahwa motif/tujuan dari harta bersama dalam masyarakat Indonesia dapat dikatakan sesuai dengan maqashid al syari'ah, akan tetapi dalam mekanisme terbentuknya harta bersama secara otomatis seperti yang dianut oleh Undang-undang No. 1 Tahun 1974 Tentang Perkawinan ini tidak sesuai dengan ketentuan kepemilikan dalam hukum Islam yaitu sebab kepemilikan yang dibenarkan oleh syara', karena akad nikah bukan merupakan sebab kepemilikan.

Ketentuan dalam Kompilasi Hukum Islam yang terkesan tidak otomatis terbentuk harta bersama dengan adanya akad nikah tentu tidak sejalan dengan Undang-undang No. 1 Tahun 1974 Tentang Perkawinan, padahal kedudukan Kompilasi Hukum Islam hanya merupakan perpanjangan tangan dari Undang-undang No. 1 Tahun 1974 Tentang Perkawinan tersebut.

Apa yang dianut oleh Kompilasi Hukum Islam ini sudah sesuai dengan ketentuan kepemilikan dalam hukum Islam, karena itulah Kompilasi Hukum Islam menyebut harta kekayaan dalam perkawinan sebagai syirkah. Menurut Penulis, kalau harta kekayaan dalam perkawinan dianggap sebagai syirkah maka tentu diperlukan akad syirkah, karena akad nikah bukan akad syirkah, inilah yang belum diterapkan dalam masyarakat Indonesia. Hal ini tentu akan sejalan dengan Undang-undang No. 1 Tahun 1974 Tentang Perkawinan yang menganut adanya harta bersama, yaitu dengan adanya akad/ kesepakatan maka akan terbentuklah harta bersama.

Terbentuknya harta bersama di Indonesia hendaknya dimulai dengan akad/kesepakatan, karena itulah pihak Kantor Urusan Agama hendaknya menyediakan formulir isian kesepakatan tentang harta kekayaan dalam perkawinan yang wajib diisi oleh calon suami dan isteri, misalnya tentang jenis harta yang akan menjadi harta bersama, berapa pembagiannya, dan lain sebagainya.

\section{Kesimpulan}

Berdasarkan uraian terdahulu dapat diketahui bahwa konsep harta bersama berasal dari hukum adat Indonesia. Dalam hukum adat Indonesia harta bersama ada apabila ada kehidupan bersama antara suami isteri, dan keduanya mempunyai kedudukan yang sama dalam masyarakat. Sedangkan prinsip garis keturunan tidak menentukan ada atau tidaknya harta bersama tersebut.

Konsep harta bersama ini tidak dikenal dalam hukum Islam, akan tetapi motif/tujuan harta bersama dalam hukum adat sesuai dengan maqashid al syari'ah, sedangkan dalam mekanisme terbentuknya harta bersama secara otomatis tidak sesuai dengan ketentuan kepemilikan dalam hukum Islam, karena itulah diperlukan adanya akad/ kesepakatan.

Ke depan, pengaturan tentang adanya harta bersama di Indonesia hendaknya dimulai dengan akad/kesepakatan, karena itulah pihak Kantor Urusan Agama hendaknya menyediakan formulir isian tentang kesepakatan harta bersama yang wajib diisi oleh calon suami dan isteri.

\section{Daftar Pustaka}

Abdul Aziz Dahlan, dkk. (ed.). 2001. Ensiklopedi Hukum Islam, ctk. Kelima, Jilid Keempat, Ichtiar Baru van Hoeve, Jakarta

Abdul Sami' al Mishri. 1990. Muqawwimat al Iqtishad al Islami, diterjemahkan oleh Dimyauddin Djuwaini. 2006. dengan judul Pilar-pilar Ekonomi Islam, Pustaka Pelajar, Yogyakarta 
Ahmad Azhar Basyir. 2007. Hukum Perkawinan Islam, ctk. Kesebelas, UII Press, Yogyakarta

B. Ter Haar Bzn, Asas-asas dan Tatanan Hukum Adat, disadur oleh Freddy Tengker. 2011. ctk. Pertama, Mandar Maju, Bandung

Dedi Susanto. 2011. Kupas Tuntas Masalab Harta Gono-Gini, ctk. Pertama, Pustaka Yustisia, Yogyakarta

Departemen Agama RI. 2004. Tinjauan Fiqh Islam terhadap Putusan Pengadilan Agama dalam Perkara Harta Bersama, Direktorat Pembinaan Peradilan Agama Direktorat Jenderal Bimbingan Masyarakat Islam dan Penyelenggaraan Haji, Jakarta

Dimyauddin Djuwaini. 2008. Pengantar Fiqh Muamalah, ctk. Pertama, Pustaka Pelajar, Yogyakarta

Hilman Hadikusuma. 2003. Pengantar Ilmu Hukum Adat Indonesia, ctk. Kedua, Mandar Maju, Bandung

Ismail Muhammad Syah. 1984. Pencaharian Bersama Suami Isteri di Aceh Ditinjau dari Sudut Undangundang Perkawinan Tabun 1974 dan Hukum Islam, Disertasi pada Program Doktor dalam Ilmu Hukum Pada Universitas Sumatera Utara, Medan

Mahsun Fuad. 2005. Hukum Islam Indonesia; dari Nalar Partisipatoris hingga Emansipatoris, ctk. Pertama, LKiS, Yogyakarta

Moh. Mukri. 2011. Paradigma Maslahah dalam Pemikiran al Gazzali; Sebuah studi Aplikasi dan Implikasi terhadap Hukum Islam Kontemporer, ctk. Pertama, Pesantren Nawesea Press, Yogyakarta

M. Tahir Azhari. 1993. "Kompilasi Hukum Islam sebagai Alternatif : Suatu Analisis Sumbersumber Hukum Islam" dalam Tim Ditbinbapera, Berbagai Pandangan Terbadap Kompilasi Hukum Islam, ctk. Pertama, Yayasan al Hikmah, Jakarta
Slamet Abdullah dan M. Muslich KS. 2010. Seabad Muhammadiyah dalam Pergumulan Budaya Nusantara, Edisi Pertama, ctk. Pertama, Global Pustaka Utama, Yogyakarta

Soerjono Soekanto. 1994. Pokok-pokok Sosiologi Hukum, ctk. Ketujuh, ed. Kesatu, RajaGrafindo Persada, Jakarta

- dan Soleman b. Taneko, Hukum Adat Indonesia, Rajawali, Jakarta

Sudarsono. 1994. Hukum Perkawinan Nasional, ctk. Kedua, Rineka Cipta, Jakarta

Syamsul Anwar. 2007. Hukum Kontrak Syariah, Bahan Kuliah Magister Hukum UII, Yogyakarta

Taqyuddin an Nabhani. 1990. An Nidlam al Iqtishadi fil Islam, diterjemahkan oleh Moh. Maghfur Wachid. 2002. dengan judul Membangun Sistem Ekonomi Alternatif; Perspektif Islam, ctk. Ketujuh, Risalah Gusti, Surabaya

Muhammad Khalid Mas'ud. 1977. Islamic Legal Philosofy: A Study of Abu Ishaq al Shatibi's Life and Thought, diterjemahkan oleh Yudian W. Asmin. 1995. dengan judul Filsafat Hukum Islam dan Perubahan Sosial, ctk. Pertama, Al Ikhlas, Surabaya

T.M. Hasbi ash Shiddieqy. 1974. Pengantar Fikih Mu'amalah, ctk. Pertama, Bulan Bintang, Jakarta

Wahbah al Zuhaili. 1989. Al Figh al Islami wa Adillatubu., ctk. Ketiga, Juz IV, Dar al Fikr, Damasqus

Yudian Wahyudi. 2007. Maqashid Syari'ah dalam Pergumulan Politik; Berfilsafat Hukum Islam dari Harvard ke Sunan Kalijaga, ctk. Ketiga, Pesantren Nawesea Press, Yogyakarta . 2011. UsbulFikih Versus Hermeneutika; Membaca Islam dari Kanada dan Amerika, ctk. Ketujuh, Pesantren Nawesea Press, Yogyakarta 